\title{
Effect of biostimulation treatments on the toxicity of oil- contaminated mangrove sediment
}

\author{
Souza-Santos, L.P. ${ }^{1 *}$; Costa, B.V.M ${ }^{1}$; Torreiro-Melo, A.G.A.G. ${ }^{1}$; \\ Araújo-Castro, C.M.V. ${ }^{1}$; Garcia, K.S. ${ }^{2}$; Lima, D.F. ${ }^{2}$ \& Oliveira, O.M.C. ${ }^{2}$ \\ ${ }^{1}$ Laboratório de Cultivo e Ecotoxicologia, Departamento de Oceanografia, Universidade Federal de Pernambuco, Av. Arquitetura s/n ${ }^{\circ}$, \\ Cidade Universitária, Recife, Pernambuco, CEP 50740-550, Brazil \\ ${ }^{2}$ Nucleo de Estudos Ambientais/Instituto de Geociências, Universidade Federal da Bahia, Rua Barão de Geremoabo, s/n, CEP 40170-290 \\ Salvador, Bahia, Brazil
}

Received December 20, 2017; Accept September 19, 2018

\begin{abstract}
Bioassays with the marine copepod Tisbe biminiensis were used to evaluate the efficiency of three bioremediation treatments on oil contaminated sediments. Two biostimulation treatments (adding NPK and OSMOCOTE fertilizers) and a natural attenuation treatment (experimental control, without fertilizers) were evaluated. The addition of NPK fertilizer had a strong lethal effect on $T$. biminiensis females probably associated to ammonium compounds, but this effect disappeared after 15 days. The OSMOCOTE releases nutrients in a gradual manner and as such, had no lethal effect on T. biminiensis females. In the natural attenuation treatment, the fecundity of $T$. biminiensis increased $200 \%$ and this indicates that natural attenuation treatment effectively attenuated the sub-lethal toxicity. Biostimulation treatments were not more efficient in obtaining lower toxicity levels of oil contaminated sediment compared to natural attenuation as the recovery of the endpoint affected by contamination (fecundity) increased at the same rate in the 3 treatments over time. In conclusion, adding fertilizers with high ammonium compound concentrations and rapid release is not recommended as a bioremediation treatment in mangroves.
\end{abstract}

Keywords: Mangrove; Oil Spill; Bioremediation; Fertilizer; Sediment.

\section{INTRODUCTION}

Mangroves are coastal ecosystems that represent the habitat, feeding and spawning areas for many species (Chapman \& Wang, 2001) and are an essential source of livelihood for coastal communities (Duke et al., 2007). Nevertheless, the mangroves have been affected by petroleum industry activities such as exploration, transport and oil refining, being classified by Gundlach \& Hayes (1978) as one of the most susceptible ecosystems to oil contamination.

Due to particular characteristics of the mangrove and high water-sediment partition coefficient of petroleum hydrocarbons (Chu \& Chan, 2000), these contaminants tend to adsorb onto the sedimentary matrix, transforming it into both a sink and a source of contamination (Burton et al.,
2002). Petroleum hydrocarbons associated with sediments can reduce the offspring production rates of copepods (Lotufo, 1997; Lotufo \& Fleeger, 1996; Wirth et al., 1998), tubificid worms (Lotufo \& Fleeger, 1996) and change the structure of benthic communities in intertidal areas impacted by oil spill (Andersen et al., 2008).

In order to avoid such impacts, cleaning strategies have been put in place with the aim of restoring oil-polluted sediments (Lofrano et al., 2017). Mechanic strategy as dredging and capping strategy usually employed in flat areas are not viable in mangroves due to complex vegetation that is found in this environment (Lofrano et al., 2017). Thus alternative approach, as bioremediation, should be required. Bioremediation strategies rely on biological potential to degrade (e.g., microbial degradation) and/or remove (e.g., 
phytoremediation) hydrocarbons present in the sediment (Dowty et al., 2001; Mills et al., 2003), causing lower impact than the use of physical structures for oil removal (Cantagallo et al., 2007). Among such strategies we highlight natural attenuation (self cleaning of the mangrove without human interference), bioaugmentation (addition of microorganisms to the impacted environment) and biostimulation (correction of the nutrient concentrations to stimulate growth of the microbiota) (Lofrano et al., 2017; Yu et al., 2005).

The biostimulation has been considered by some authors as more effective compared to other strategies to remove polyaromatic hydrocarbons from beach and mangrove sediments contaminated with oil (Xu et al., 2005a; Yu et al., 2005). Yu et al. (2005) showed that biostimulation has removed $97 \%$ of contamination by fluorene, phenanthrene and pyrene in mangrove sediments after 4 weeks. The results obtained in wetland sediments (Mills et al., 2004) and in seawater (Huang et al., 2008; Nikolopoulou \& Kalogerakis, 2008) corroborate the effectiveness of biostimulation strategies. The bioremediation strategies have been primarily evaluated with chemical parameters, but there are some records using biological indicators in the evaluation of these strategies in marine sediment (Mueller et al., 2003; Sabean et al., 2009). Sabean et al. (2009) were able to assess the biostimulation efficiency by quantifying deformities in foraminifers' tests present in the sediment and Mueller et al. (2003) used bioassays with bacteria and amphipod.

Several organisms were usually used to test the ecotoxicological effects of remediation strategies as bacteria, mollusks, annelids, crustaceans (mainly amphipods) and fish (Libralato et al., 2018), but there was no record using benthic copepods for this purpose. Benthic copepods live in close contact with the sedimentary matrix, are sensitive to the anthropogenic input of contaminants (Coull, 1999) and were already used for toxicity evaluation of sediment samples (Bejarano et al., 2004; Lotufo, 1997; Lotufo \& Fleeger, 1997; Maciel et al., 2015). As copepods represent a food resource for many predators, it can transfer contaminants to higher trophic levels (Coull, 1990; DiPinto \& Coull, 1997). Tisbe biminiensis VolkmannRocco 1973 is a benthic copepod that has been cultivated for many years in laboratory (Ribeiro \& Souza-Santos, 2011) and nowadays is being used for toxicity tests to assess sediment quality due to its sensitivity to contaminants (Araújo-Castro et al., 2009; Maciel et al., 2015; Oliveira et al., 2014).

A mangrove area at the northeastern area of Todos os Santos Bay (Brazil) submitted to petroleum industry impact for more than 70 years was characterized as contaminated (Venturini \& Tommasi, 2004), presenting total polyaromatic hydrocarbon concentrations varying from 8 to $4163 \mathrm{ng} \mathrm{g}^{-1}$ dry weight. The toxic effects of this local contamination was evaluated by benthic communities structure analysis (Peso-Aguiar et al., 2000; Venturini et al., 2008), growth dynamics of seedlings from the mangrove (Orge et al., 2000), sediment bioassays with Litopenaeus vannamei larvae (sub-lethal effect) (Evangelista et $a l ., 2005$ ) and interstitial and surface water bioassays with larva of Artemia salina (lethal effect), Echinometra lucunter (sub- lethal effect) and Crassostrea rhizophorae (sub-lethal effect) (Nascimento et al., 2000). In this context, the ecotoxicological aspects of a remediation program should be evaluated to design future in situ experiments in this area. The aim of this study was to determine by means of bioassays with the benthic copepod T. biminiensis the effectiveness of two biostimulation treatments applied in a mesocosm system using oil-polluted sediments amended with two agricultural fertilizers NPQ and OSMOCOTE.

\section{MATERIALS AND METHODS}

\section{Study Area}

Sediment samples were collected in Todos os Santos Bay (Bahia, Brazil), located between latitudes $12^{\circ} 39^{\prime}-13^{\circ} \mathrm{S}$ and longitudes $38^{\circ} 32^{\prime}-38^{\circ} 50^{\prime} \mathrm{W}$ (Fig. 1). It is the largest bay in Brazil with approximately $450 \mathrm{~km}$ of coastline and is covered by extensive mangroves (Venturini et al., 2008). Petroleum exploration in the bay started in 1940 and led to the construction of the Landulfo Alves Mataripe Refinery (RLAM) as well as a maritime terminal, both built in the northeastern section of the bay (Fig. 1). In 1998, an effluent emission channel was built to transport the wastes from the refinery to a mangrove area located at the RLAM vicinity (Orge et al., 2000). The oils produced in Todos os Santos Bay were classified as light oils and the RLAM refines oils from diverse sources (Gaglianone \& Trindade, 1988).

\section{Collection of sediment and bioremediation treatments}

Oil-contaminated sediment was collected from the intertidal region of the São Paulo river estuary (Fig. 1),

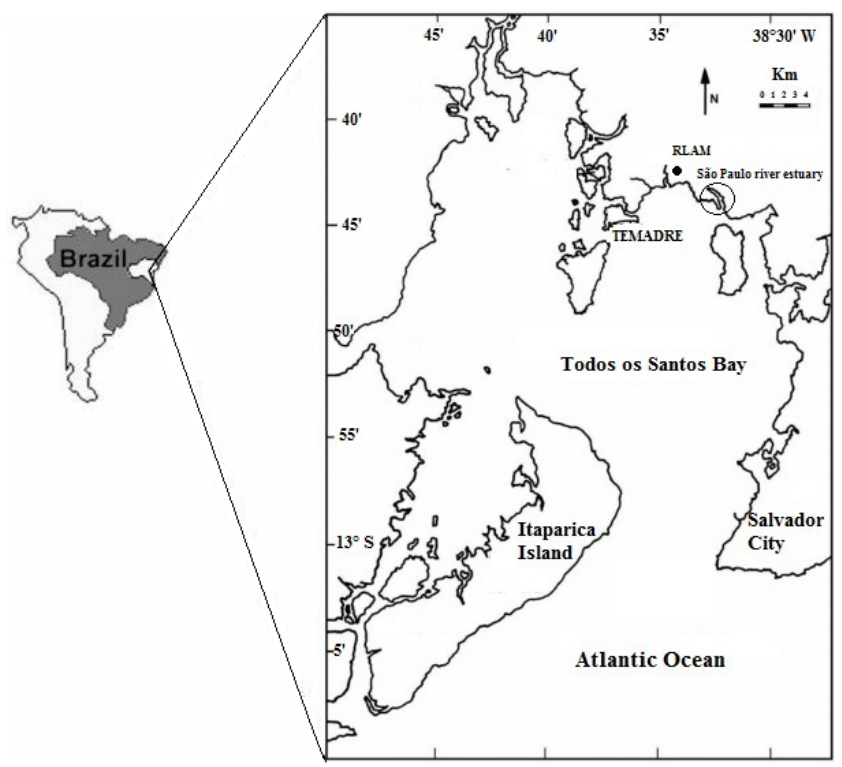

Figure 1 - Location of Todos os Santos Bay, with the estuary of the São Paulo river, the Landulfo Alves Mataripe Refinery (RLAM) and Marine Terminal of Madre de Deus (TEMADRE) (modified from Peso-Aguiar et al., 2000). 
an area near the refinery, during low tide in September of 2008. In this area the oil can be observed flowing up from the sediment deep layers in some points and not homogeneously distributed in the surface as would be expected in recent oil spill. For this reason, sediment cores (72 samples) were collected using stainless steel core $(30 \mathrm{~cm}$ high and $10 \mathrm{~cm}$ diameter), pooled and homogenized. Soon after homogenization, the oil-contaminated sediment was divided into three portions to start the three bioremediation treatments. The first treatment was called natural attenuation and consisted of the original contaminated sediment without any nutrient treatment (i.e. fertilizer addition). The other two treatments represented biostimulation treatments, one called NPK treatment and other OSMOCOTE treatment in which NPK and OSMOCOT fertilizers were added to the sediment. The fertilizers were added at concentration of $0.5 \mathrm{~g} \mathrm{Kg}^{-1}$ and were composed as follow: ammonium sulfate $\left(\left(\mathrm{NH}_{4}\right)_{2} \mathrm{SO}_{4}\right)$, ammonium phosphate $\left(\left(\mathrm{NH}_{4}\right)_{3} \mathrm{HPO}_{4}\right)$, potassium chloride $(\mathrm{KCl})$ and cottonseed meal, at $10 \mathrm{~N}: 10 \mathrm{P}: 10 \mathrm{~K}$ proportion. Both fertilizers are hydrosoluble, but NPK fertilizer releases the nutrients readily whereas the OSMOCOTE fertilizer is of slow release type.

\section{Experimental Design}

After the addition of fertilizers, the sediment was packed into glass columns (30 $\mathrm{cm}$ high and $5 \mathrm{~cm}$ diameter) open in both ends. The glass columns had been previously lined with white cotton bags to keep the sediment in columns and allow the passage of light and water. These columns were fixed on wooden supports and each support maintained 8 columns (Fig. 2). The wooden supports with the 8 columns were accommodated in glass aquariums with the following dimensions: $30 \times 40 \times 50 \mathrm{~cm}$ (width $\times$ length $\times$ depth; $60 \mathrm{~L}$ volume). Each aquarium simulated a specific bioremediation treatment (natural attenuation and biostimulation treatments with NPK or OSMOCOTE fertilizers) and to each bioremediation treatment there were 3 replicates of aquariums (totaling 9 aquariums). The aquariums were filled with the local estuarine water (São Paulo river estuary) by means of a pump circulation system and renewed daily throughout the experiment. This allowed the simulation of the tides, but the aquariums were never empty during simulation of low tide and the sediment was always moistened. The tidal simulation was made by means of two taps located on the top and bottom of the tanks, which allowed the control of the water level.

In order to evaluate the toxicity of oil-contaminated sediment, the glass columns were removed on $1,8,15,30,45$, 60 and 90 days after the introduction of the oil-contaminated sediment in glass columns. After the glass columns were removed, sediments were homogenized and samples were stored until $48 \mathrm{~h}$ in glass containers, refrigerated and transported by plane to the laboratory at Recife (Pernambuco) to the start of ecotoxicological bioassays.

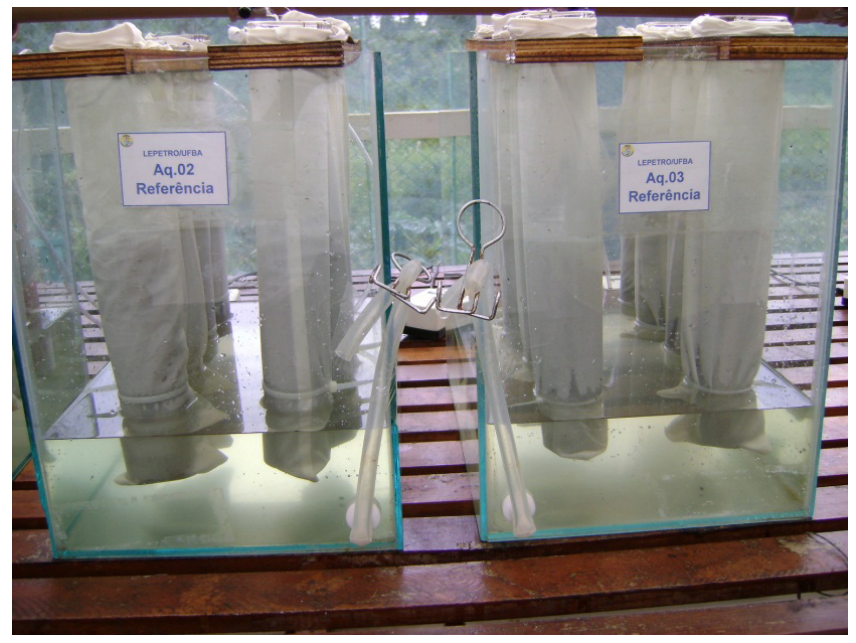

Natural attenuation

$\underline{\text { NPK }}$

OSMOCOTE
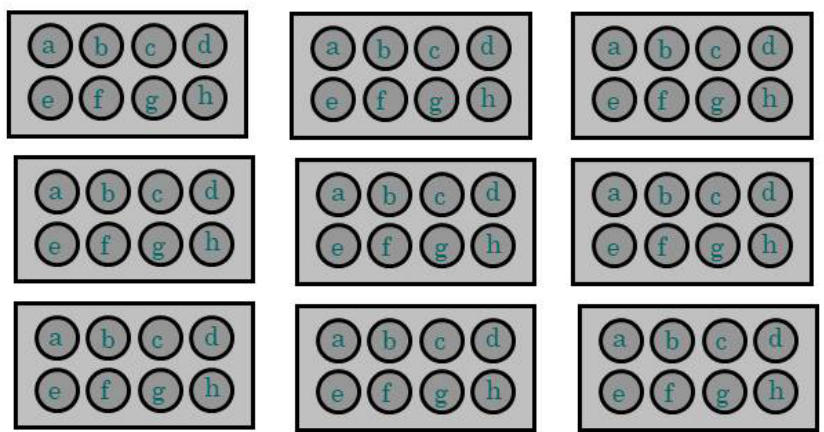

Figure 2 - The nine aquariums with eight sediment cores used to test biostimulation treatments (photo of the authors). Each core $\mathbf{a}$ to $\mathbf{g}$ are sampled at 1,8,15,30, 45, 60 and 90 days after the start of bioremediation experiment.

\section{Cultivation of copepods and bioassays with Tisbe biminiensis}

The benthic marine copepod Tisbe biminiensis has been cultivated in the laboratory according to the method established by Ribeiro \& Souza-Santos (2011). The cultures are kept in polyethylene containers without substrate and fed with fish ration plus Thallassiosira weissflogii or Chaetoceros calcitrans diatom.

Bioassays with $T$. biminiensis were carried out following the established protocol described by Araújo-Castro et al. (2009). The sediment samples were sieved through a $64 \mu \mathrm{m}$ mesh (to discard any predator) and approximately $2 \mathrm{~g}$ of wet sediment $<64 \mu \mathrm{m}$ were weighed and placed into glass containers $(4.3 \mathrm{~cm}$ diameter and $5.8 \mathrm{~cm}$ high with a plastic cap and $60 \mathrm{~mL}$ capacity). Diatom suspension $(20 \mathrm{~mL})$ was added as food at a concentration of $0.2 \mu \mathrm{g} \mathrm{Chl}-\mathrm{a} \mathrm{mL} \mathrm{mL}^{-1}$ in all containers, measured as proposed by Lorenzen (1967). After an interval of $24 \mathrm{~h}$ for mud sedimentation, 10 ovigerous females were placed into each container. The containers were incubated at $25^{\circ} \mathrm{C}$ at $12 \mathrm{~h} / 12 \mathrm{~h}$ light/dark photoperiod at an incubator. The bioassays lasted 7 days with food addition taking place every other day. Dissolved oxygen concentration (D.O.), $\mathrm{pH}$ and salinity 
were determined at the beginning and end of the bioassay with oximeter, $\mathrm{pHmeter}$ and refractometer, respectively. At the end of the bioassay, all contents of the containers were stained with Rose-Bengal and fixed with formaldehyde (4\%) to make the counts. The endpoints evaluated were survival of T. biminiensis females (stained females are considered alive), total fecundity (number of nauplii plus copepodites produced by the ten females) and percentage of copepodites (indicating the development of the offspring).

Non-toxic sediment was collected from the estuary of the Maracaípe river estuary (Pernambuco, Brazil) to serve as laboratory control and permit to detect sediment toxicity at experimental samples (Araújo-Castro et al., 2009). This control sediment was also sieved through a $64 \mu \mathrm{m}$ mesh and there were five replicates for each bioassay. For the bioremediation treatments, three sub-replicates were used for sediments extracted from each column (these values were later transformed into a general mean of each aquarium). Tests were carried out alongside the bioassays with the reference substance $\mathrm{K}_{2} \mathrm{Cr}_{2} \mathrm{O}_{7}$ in order to analyze the sensitivity of the copepods used in these experiments.

\section{Physicochemical analysis of sediments}

Physicochemical analysis was also carried out on the sediment after 1, 8, 15,30, 45, 60 and 90 days of bioremediation treatments. The following parameters were measured: ammonium $\left(\mathrm{NH}_{4}^{+}\right)$concentration using the Kjeldahl method of wet digestion (Silva, 1999) and total organic carbon (TOC) (Walkey-Black, 1947). Sediment granulometry was carried out by laser diffraction method (Garcia, 2005).

\section{Statistical analysis}

The two-way Analysis of Variance (ANOVA) was carried out to evaluate both time and treatment effects (laboratory control, Natural Attenuation and NPK or OSMOCOTE biostimulation) on survival, fecundity and percentage of copepodites of $T$. biminiensis. Tukey's test was carried out $a$ posteriori to identify the significant differences among means. These parametric tests were done after verifying the normality and homogeneity of variances. A $\log _{10}$ transformation was applied to the fecundity and percentage of copepodites data that were submitted to two-way ANOVA. Linear regression analysis between endpoints and the sediment ammonium concentrations was carried out to evaluate possible relationships between these variables. The significance level was 0.05 in all analysis. The lethal concentration for $50 \%$ of the organisms $\left(\mathrm{LC}_{50}\right)$ after $96 \mathrm{~h}$ was obtained by the Trimmed Spearman-Karber method (Hamilton et al., 1977) in the reference tests and this data were also compared to the control chart established by Araújo-Castro et al. (2009).

\section{RESULTS}

\section{Toxicity of bioremediation treatments}

In all experiments, the $96 \mathrm{~h} \mathrm{LC}_{50}$ values of the reference substance were within the levels established by Araújo-Castro et al. (2009). This indicates that the organisms used in the bioassays exhibited adequate sensitivity. In the laboratory control sediment, the average ( \pm standard deviation) Tisbe biminiensis survival, fecundity and copepodites percentage were $95 \%( \pm 4 \%), 367( \pm 85)$ individuals and $20 \%( \pm 17 \%)$, respectively, throughout experiment (Fig. 3).

The oil-contaminated sediment from the estuary of the São Paulo river could be represented by Natural Attenuation treatment at the first day of experiment. Lethal effect to Tisbe biminiensis females were not observed (Fig. 3a); however an intense sub-lethal effect was evidenced, considering the fecundity reduction (Fig. 3b). There was also a significant increase in the percentage of copepodites at first day of the natural attenuation treatment when compared to the laboratory control (Fig. 3c).

The ANOVA indicated that bioremediation time and treatment had a significant effect on endpoints with significant interactions between both factors, excepting for survival, in which time had marginal significance $(p=0.055)$ and interaction between factors was not significant $(\mathrm{p}=0.1)$ (Tab. 1). Considering all bioremediation time together, the natural attenuation, NPK and OSMOCOTE treatments had significant lower means of female survival compared to laboratory control. The NPK treatment also exhibited a significant reduction of female survival in comparison to OSMOCOTE treatment. Considering pairwise comparison, soon after adding NPK fertilizer (1 day), there was a drastic reduction in female survival (Fig. 3a). As bioremediation time passed there was a recovery in the survival at day 15 at NPK treatment, when there was no more difference between the natural attenuation,

Table 1 - Results of two-way Analysis of Variance $(\alpha=0.05)$ considering the effects of factors bioremediation time, treatment and its interactions on survival, fecundity (nauplii + copepodite) and percentage of copepodites in bioassays with Tisbe biminiensis. df: degree of freedom.

\begin{tabular}{lccc}
\hline Factors $(\mathrm{df})$ & \multicolumn{3}{c}{ F-values $(\mathrm{p}$-value) } \\
& Survival & Endpoints \\
& $2.34(0.055)$ & $21.63(<0.001)$ & $13.10(<0.001)$ \\
Time $(5,48)$ & $10.28(<0.001)$ & $79.89(<0.001)$ & $40.8(<0.001)$ \\
Treatment $(3,48)$ & $1.12(0.1)$ & $10.68(<0.001)$ & $5.83(<0.001)$ \\
Interaction $(15,48)$ & &
\end{tabular}



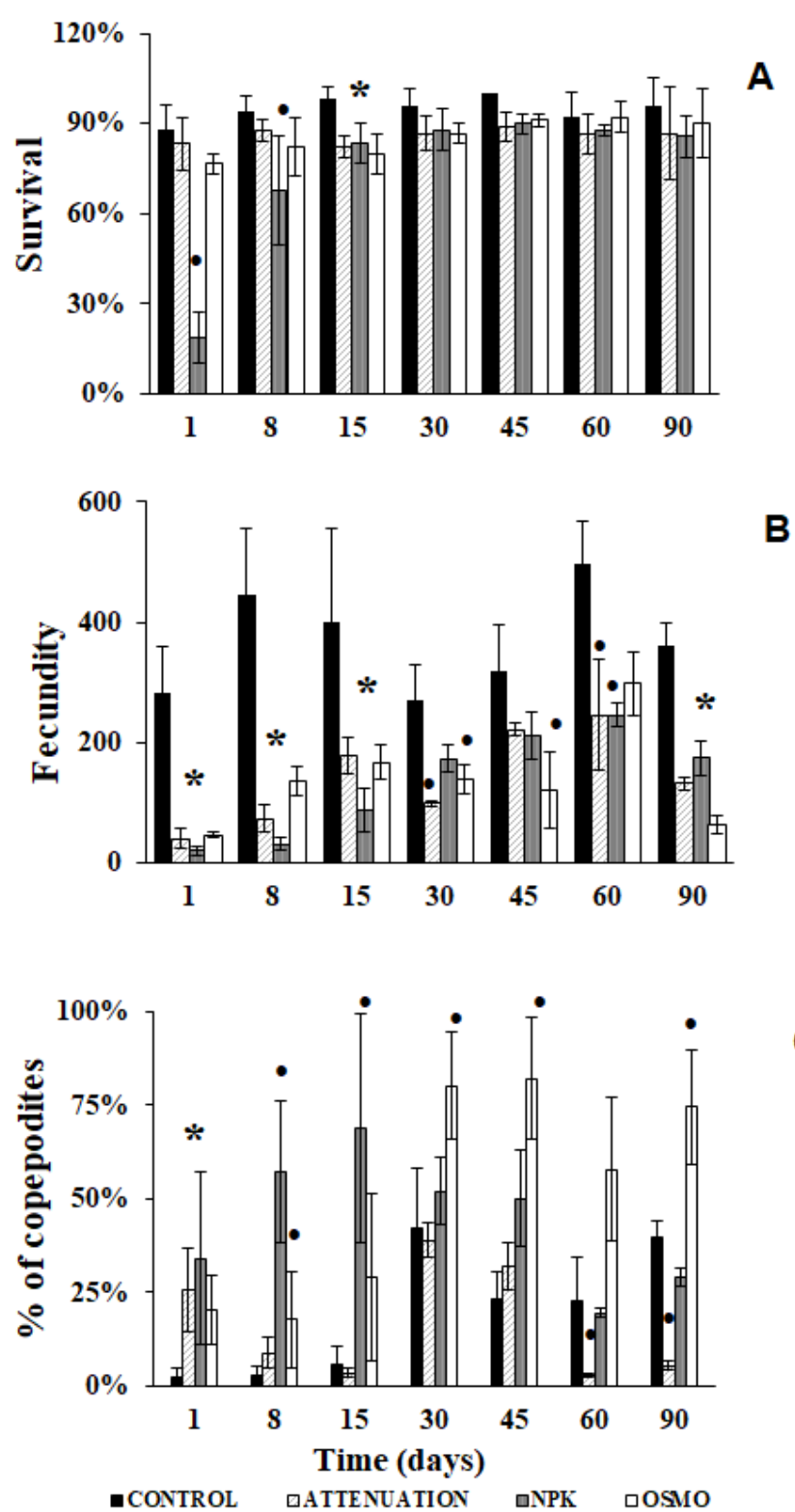

Figure 3 - Mean rates ( \pm 1 standard deviation) of survival (A), fecundity (nauplii + copepodites) (B) and percentage of copepodites in the offspring (C) of T. biminiensis in the four treatments (laboratory control, natural attenuation, NPK and OSMOCOTE) over time. Asterisks indicate that all experimental treatments were significantly different to the laboratory control.

Black dots indicate that one experimental treatment (natural attenuation,

NPK or OSMOCOTE) was significantly different to the laboratory control.

NPK and OSMOCOTE treatments and from day 30 onwards with no more difference in comparison to laboratory control (Fig. 3a).

Considering all bioremediation time together, the fecundity increased significantly over time from day 1 to day 60 of bioremediation (Fig. 3b) although the means in the natural attenuation, NPK and OSMOCOTE treatments were significantly lower than in the laboratory control treatment. There was no difference in fecundity rates between treatments with NPK or OSMOCOTE. However, fecundity was significantly lower in the NPK treatment than in the natural attenuation treatment.
The copepodites' percentage varied significantly over bioremediation time with a significant increase on days 30 and 45 relatively to initial bioassay (day 1 ). At the end of the bioremediation time (day 90), the percentage of copepodites was not significantly different in comparison to initial bioassay (day 1). The NPK and OSMOCOTE treatments had no significant differences in the percentage of copepodites. However, this endpoint was significantly higher in both of these biostimulation treatments than in the attenuation natural treatment and laboratory control.

\section{Ammonium concentrations and relationships with $T$. biminiensis' endpoints}

The sediment grain size analysis indicated $40 \%$ of mud. The average TOC percentage throughout experiment was $4.7 \%$. The ammonium concentration in this sediment was $2.36 \mathrm{mg} \mathrm{Kg}^{-1}$, but soon after the addition of NPK fertilizer the ammonium concentration increased to $323 \mathrm{mg} \mathrm{Kg}^{-1}$ (Fig. 4). The ammonium concentration decreased over time in the NPK treatment. The ammonium concentration values were low for natural attenuation and OSMOCOTE treatments. In the OSMOCOTE treatment, the ammonium concentration increased until day 30 (58 $\mathrm{mg} \mathrm{Kg}^{-1}$ ) and then decreased (Fig. 4).

There was a significant negative linear relation between female survival and the ammonium concentration (Tab. 2). There was a negative significant exponential relation between T. biminiensis fecundity and the ammonium concentration, but there was a positive significant geometrical relation between copepodite percentage and the ammonium concentration in the sediment (Tab. 2).

\section{DISCUSSION}

Biostimulation treatments must be strictly evaluated in relation to their effectiveness before their application in oil-contaminated mangrove sediment. The treatment will be effective if reduce the contaminant concentrations

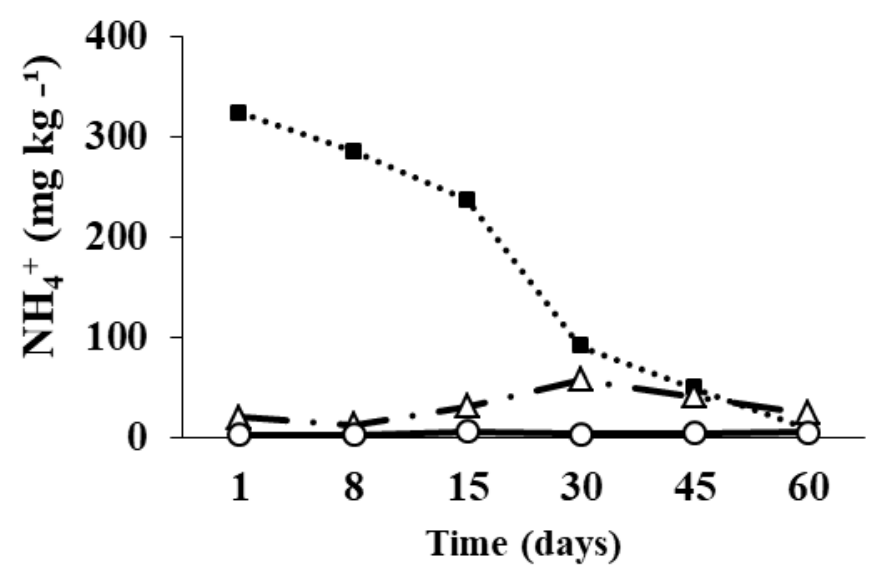

Figure 4 - Variation of the ammonium $\left(\mathrm{NH}_{4}^{+}\right)$concentration $\left(\mathrm{mg} \mathrm{kg}^{-1}\right)$ in sediment over time and in the treatments evaluated. Natural attenuation (open circles), NPK (filled square) and OSMOCOTE (open triangles). 
Table 2 - Results of the regression analyses between ammonium concentration $\left(\mathrm{NH}_{4}^{+}\right)$in sediments $\left(\mathrm{mg} \mathrm{Kg}^{-1}\right)$ and survival, fecundity (nauplii + copepodite) and percentage of copepodites in bioassays with Tisbe biminiensis.

\begin{tabular}{lcccc}
\hline & Equation & $\mathrm{R}^{2}$ & $\mathrm{p}$ & Relationship \\
\hline Female survival & $\mathrm{y}=8.8932-0.0172 \mathrm{x}$ & 0.80 & $<0.001$ & inverse linear \\
Fecundity & $\mathrm{y}=151.8637 \mathrm{x} \mathrm{e}^{\left(-0.0061^{*} \mathrm{x}\right)}$ & 0.45 & $<0.001$ & exponential \\
Percentage of copepodites & $\mathrm{y}=7.9395 \mathrm{x}^{(0.4161)}$ & 0.24 & 0.025 & geometrical \\
\hline
\end{tabular}

without produce toxic effects on the biota established in the mangrove (Cantagallo et al., 2007). Effects related to the in-situ application of inorganic fertilizers in mangrove include changes in the benthic community structure (Santos et al., 2009; Schratzberger et al., 2003) that may make it impossible to ecologically restore the oil-impacted mangrove (Haimi, 2000). The results of the present study are the first ones reporting toxic effects of biostimulation treatments on population parameters using a benthic copepod as model.

The main sub-lethal effect of contaminated sediment of São Paulo estuary is the reduction of the number of offspring produced after 7 days of incubation of ovigerous females. This reduction may be a result of reduction of female egg production, offspring survival, or both factors together. The increase in the fecundity of Tisbe biminiensis female throughout the 90 days of the bioremediation experiment was the most sensitive endpoint to evaluate the effectiveness of biostimulation treatments. In the natural attenuation treatment, the fecundity of T. biminiensis increased $200 \%$ and this indicates that natural attenuation treatment effectively attenuated the toxicity of oil-contaminated sediment. The effectiveness of the natural attenuation in oil-contaminated mangrove sediment has been quantified by monitoring the hydrocarbons concentrations over time, with removal rates greater than 90\% (Mills et al., 2003; Yu et al., 2005). These high rates of degradation of contaminants are primarily related to microbial degradation processes (Prince, 1993). In the present experiments the hydrocarbons were not quantified because of technical problems then it could not be measure the real efficiency in their degradation during the bioremediation experiments, but it can be suggested from the observed reduction of sub-lethal toxicity of sediment.

The lack of significant differences in copepod fecundity between OSMOCOTE and natural attenuation treatments and lower fecundity at NPK treatment in comparison to natural attenuation suggested that biostimulation treatments were not more efficient than natural attenuation treatment. This result suggests that during the 90 days of experiment the biostimulation treatments failed to enhance the degradation rates of toxic hydrocarbons in comparison to the natural attenuation treatment. The ineffectiveness herein described contrasts with results found previously by other authors as Yu et al. (2005) and Mills et al. (2004) that demonstrated the effectiveness of biostimulation treatments promoting the reduction in the concentration of hydrocarbons. This contrast can be solved in light of the theory proposed by Smith et al. (1998), who associated microbial community composition with the proportion of nutrients provided. During biostimulation treatments, nutrient proportions need to favour the growth of natural sediment microbiota with the greatest potential for oil degradation in order to obtain efficient bioremediation treatments. In the present study, the proportion of nutrients in fertilizers used in the biostimulation treatments could not favoured the growth of those organisms with greater potential for degradation, resulting in the rather similar rates of attenuation between biostimulation and natural attenuation treatments. The high nutrient contents in mangrove sediments and the long-term contamination in this area could also be also responsible for a natural selection of an indigenous microbiota rich in species capable to degrade oil in the 3 treatments tested.

A sharp reduction in female $T$. biminiensis survival and fecundity occurred at 1 day of bioremediation experiment after the addition of NPK, and it must be associated with the composition of this fertilizer. The NPK fertilizer contained a high proportion of ammonium compounds, as ammonium sulfate and ammonium phosphate, and increased the ammonium concentrations to $323 \mathrm{mg} \mathrm{Kg}^{-1}$ in the sedimentary matrix. The increase of the ion ammonium would promote the increase of non-ionized ammonia, that is very toxic, as both states are always in chemical equilibrium related to $\mathrm{pH}$ values that varied from 7.2 to 7.9 in the aquarium water during all bioremediation time. Thus in situ applications at such concentrations may represent a high risk to benthic copepod populations living in the mangroves. A review of ammonium toxicity to copepods can be seen in the Table 3 and Fig. 5; the median $\mathrm{LC}_{50}$ for these compounds was estimated in 0.91 mg L ${ }^{-1}$ (Buttino, 1994; Kegley et al., 2011; Linden et al., 1979). It was previously shown that copepods have low rate of excretion of ammonium and high levels of ammonium in the water have an inhibitory effect on the excretion (Camargo \& Alonso, 2006; Miller \& Glibert, 1998), thus causing a rapid increase in the concentration of the internal body. These results demonstrated the negative impact of the use of fertilizers with a high ammonium concentration in biostimulation treatments and the need to strictly evaluate biostimulation treatments by toxicity bioassays. There was very few lethal affect associated with the addition of OSMOCOTE fertilizer (day 15 of bioremediation), probably due to its slow nutrient release, but this fertilizer is still underutilized in the biostimulation treatments (Xu et al., 2005a; Xu et al., 2005b). 
The significant negative relation between survival and the ammonium concentration (Tab. 2), with a determination coefficient $\left(\mathrm{R}^{2}\right)$ of $80 \%$, could indicate a preponderant effect of biostimulation treatments on $T$. biminiensis survival. The toxic effect related to high total ammonia (ammonium + non-ionized ammonia) compounds concentrations in the sediment (Ankley et al., 1990) can difficult the interpretation of bioassay results evaluating the effectiveness of biostimulation treatments (Ankley et al., 1994), because the effect associated with total ammonia can hinder the possible positive effect of a higher degradation of oil.

Our results show that interpreting the increase of percentage of copepodites and the increase of the developmental rates

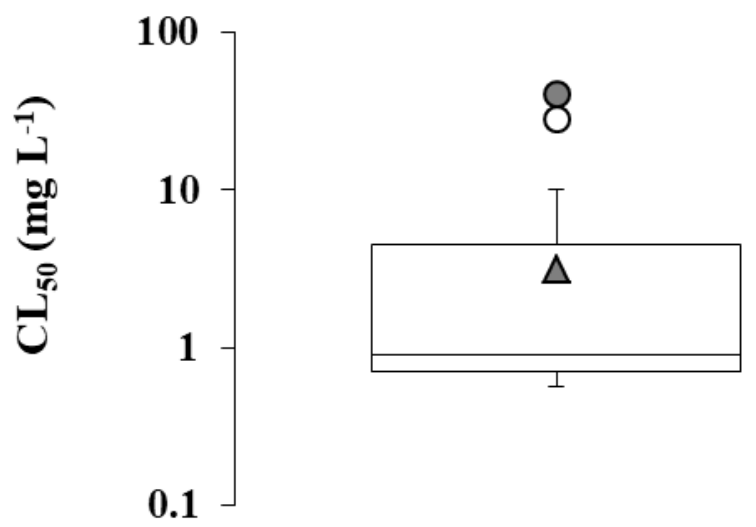

\section{Copepods $(\mathbf{N}=9)$}

Figure 5 - Box plot showing the $\mathrm{LC}_{50}$ variation of ammonium compounds for copepods, data in Table 3. The top bar indicates the highest values and the bottom bar the lowest $\mathrm{LC}_{50}$ value recorded. The symbols above the top bar indicate outliers. The triangle equivalent to non-ionized amonia $\mathrm{LC}_{50}$ to T. biminiensis and the highest outlier equivalent to ammonium $\mathrm{LC}_{50}$ to $T$. biminiensis. at contaminated sediment of São Paulo river estuary and in the biostimulation treatments during almost all 90 days of incubation time is not an easy task. Several hypotheses could be suggested. One of those would be that hormesis (Calabrese \& Baldwin, 1997) is occurring and the exposure to low concentration of some contaminant could stimulate the larval development of copepods. This increase in development rate was also described by Bejarano et al. (2006) for the copepod Amphiascus tenuiremis exposed to $10 \%$ crude oil water hydrocarbon accommodated fraction (WAFs), although at higher concentrations the development was delayed. The same authors suggested that this compensatory response could be an effect of the cytochrome P450 induction and increased secretion of 20-hydroxiecdisone hormone, which is responsible for molting in crustaceans. This process could be a physiological response to anticipate reproduction at disturbed environments. A second hypothesis is that as nauplii were born and developed during the seven days of the bioassay, the less sensitive copepodites (probably those hatched from former eggs) had survived better to contaminants, while the nauplii and early eggs did not have the same success in developing, and therefore copepodites dominated the offspring at the end of seven days. A third hypothesis is that the offspring died as egg, nauplii or copepodite, so a lower number of copepods would compete for food in the recipients. The rate of development of $T$. biminiensis is greatly affected by the availability and quality of food (Pinto et al., 2001) and the diet of the benthic copepod is varied and includes diatoms, bacteria, fungus and debris (Hicks \& Coull, 1983). This last hypothesis could also explain the higher percentage of copepodites in both biostimulation treatments relative to the natural attenuation treatment and laboratory control as the increase of inorganic nutrients should promote the increase of microbial biomass in these treatments and food supply for the development of copepods. Ramsay et al. (2000) studied the microbial population size in oil contaminated sediments and sediments treated with OSMOCOTE fertilizer and

Table 3 - Review of lethal concentration (LC) of dissolved inorganic nitrogen chemical species to copepods.

\begin{tabular}{|c|c|c|c|c|c|}
\hline Species & Life Stage & Compound & Time (h) & $\begin{array}{c}\mathrm{LC}_{50} \\
\left(\mathrm{mg} \mathrm{L}^{-1}\right)\end{array}$ & Reference \\
\hline Acartia clausi & Adult & Non-ionized ammonia & 24 & 0.91 & Butino et al. (1994) \\
\hline \multirow[t]{2}{*}{ Acartia hudsonica } & Egg & Ammonium chloride & 48 & 0.57 & PAN Database \\
\hline & Egg & Ammonium chloride & 48 & 0.82 & PAN Database \\
\hline \multirow[t]{2}{*}{ Acartia tonsa } & Egg & Ammonium chloride & 48 & 0.71 & PAN Database \\
\hline & Egg & Ammonium chloride & 48 & 0.56 & PAN Database \\
\hline Eucalanus elongatus & Adult & Ammonium chloride & 96 & 28.5 & PAN Database \\
\hline Nitocra spinipes & & Non-ionized ammonia & 96 & 4.5 & $\begin{array}{l}\text { Linden et al. (1979) } \\
\text { Araújo (unpublished }\end{array}$ \\
\hline Tisbe biminiensis & Adult & Non-ionized ammonia & 96 & 3.16 & $\begin{array}{c}\text { data) } \\
\text { Araújo (unpublished } \\
\text { data) }\end{array}$ \\
\hline
\end{tabular}


found that the microbial population size increased by $10^{3}$ after the fertilizer was added, and this increase can be very advantageous for meiofauna organisms (Coull, 1999; Pascal et al., 2009). The positive logarithmic relationship between the percentage of copepodite and ammonium concentration could be explained by these three hypotheses.

\section{CONCLUSIONS}

Bioassays with Tisbe biminiensis proved to be an efficient tool in determining the effects of bioremediation treatments applied to contaminated mangrove sediments. The biostimulation treatments were not effective in attenuating the toxicity of sediment contaminated with oil relatively to the natural attenuation, probably due to the natural high nutrient content of mangrove sediments. The use of fertilizers with a high proportion of ammonium compounds is not recommended as bioremediation strategies for mangrove sediments. It is essential to consider factors that can interfere with the interpretation of bioassay results, such as the concentration of ammonium compounds. Further experiments should measure the hydrocarbons concentrations to evaluate the chemical degradation and test other remediation strategies as for instance the bioaugmentation strategy with selected microorganisms that enhance the hydrocarbon degradation.

\section{ACKNOWLEDGMENTS}

This work was supported by the Financiadora de Estudos e Projetos (FINEP) and Petrobras inside the Rede Cooperativa em Recuperação de Áreas Contaminadas por Óleo (RECUPETRO) as well as Resíduos Líquidos do Nordeste (RELINE). The authors are also grateful to the Conselho Nacional de Desenvolvimento Científico e de Tecnológico (CNPq) for granting scholarships.

\section{REFERENCES}

ANDERSEN, L.E., MELVILLE, F., JOLLEY, D.F. 2008. An assessment of an oil spill in Gladstone, Australia - Impacts on intertidal areas at one month post-spill. Mar. Pollut. Bull., 57 (2): 607-615. https://doi.org/10.1016/j.marpolbul.2008.09.022.

ANKLEY, G.T., BENOIT, D.A., BALOGH, J.C., REYNOLDSON, T.B., DAY, K.E., HOKE, R.A. 1994. Evaluation of potential confounding factors in sediment toxicity tests with 3 fresh-water benthic invertebrates. Environ. Toxicol. Chem., 13 (4): 627-635. https://doi.org/10.1002/etc.5620130412.

ANKLEY, G.T., KATKO, A., ARTHUR, J.W. 1990. Identification of ammonia as an important sediment-associated toxicant in the lower fox River and green bay, Wisconsin. Environ. Toxicol. Chem., 9 (3): 313-322. http://dx.doi.org/10.1002/ etc. 5620090307.

ARAUJO-CASTRO, C.M. V, SOUZA-SANTOS, L.P., TORREIRO, A.G.A.G., GARCIA, K.S. 2009. Sensitivity of the marine benthic copepod Tisbe biminiensis (Copepoda, Harpacticoida) to potassium dichromate and sediment particle size. Brazilian J. Oceanogr., 57 (1): 33-41. http://dx.doi.org/10.1590/S167987592009000100004 .
BEJARANO, A.C., MARUYA, K.A., CHANDLER, G.T. 2004. Toxicity assessment of sediments associated with various land-uses in coastal South Carolina, USA, using a meiobenthic copepod bioassay. Mar. Pollut. Bull., 49 (1-2): 23-32. https:// doi.org/10.1016/j.marpolbul.2004.01.004.

BEJARANO, A.C., CHANDLER, G.T., HE, L., Coull, B. C. 2006. Individual to population effects of South Louisiana crude oil water hydrocarbon accomodated fraction (WAFs) on a marine meiobenthic copepod. J. Exp. Mar. Bio. Ecol., 332 (1): 49-59. https://doi.org/10.1016/j.jembe.2005.11.006.

BURTON, G.A., DENTON, D.L., HO, K., IRELAND, S. 2002. Sediment toxicity testing: issues and methods. In: Hoffman, D.J., Rattner, B.A., Burton, G.A., Cairns, J. (Eds.), Handbook of Ecotoxicology. Lewis Publishers, Boca Raton, pp. 112-143.

BUTTINO, I. 1994. The effect of low concentrations of phenol and ammonia on egg production rates, fecal pellet production and egg viability of the calanoid copepod Acartia clausi. Mar. Biol., 119 (4): 629-634. http://dx.doi.org/10.1007/BF00354327.

CALABRESE, E. J., BALDWIN, L. A. 1997. The dose determines the stimulation (and poison): development of a chemical hormesis database. Int. J. Toxicol., 16 (6): 545-559. https://doi. org/10.1080/109158197226874.

CAMARGO, J.A., ALONSO, A. L. 2006. Ecological and toxicological effects of inorganic nitrogen pollution in aquatic ecosystems: A global assessment. Environ. Int., 32 (6): 831-849. https://doi.org/10.1016/j.envint.2006.05.002.

CANTAGALlO, C., MILANELLI, J.C., DIAS-BRITO, D. 2007. Limpeza de ambientes costeiros brasileiros contaminados por petróleo: uma revisão. Panam. J. Aquat. Sci., 2(1): 1-12.

CHAPMAN, P.M., WANG, F. 2001. Assessing sediment contamination in estuaries. Environ.Toxicol. Chem., 20(1): 3-22. http://dx.doi.org/10.1002/etc.5620200102.

CHU, W., CHAN, K. 2000. The prediction of partitioning coefficients for chemicals causing environmental concern. Sci. Total Environ., 248 (1): 1-10. https://doi.org/10.1016/S00489697(99)00472-6.

COULL, B.C. 1990. Are members of the meiofauna food for higher trophic levels? Trans. Am. Microsc. Soc., 109 (3): 233-246. DOI: $10.2307 / 3226794$.

COULL, B.C. 1999. Role of meiofauna in estuarine soft-bottom habitats. Aust. J. Ecol., 24: 327-343. https://doi.org/10.1046/ j.1442-9993.1999.00979.x.

DIPINTO, L.M., COULL, B.C. 1997. Trophic transfer of sedimentassociated polychlorinated biphenyls from meiobenthos to bottom-feeding fish. Environ. Toxicol. Chem., 16 (12): 25682575. http://dx.doi.org/10.1002/etc.5620161219.

DOWTY, R.A., SHAFFER, G.P., HESTER, M.W., CHILDERS, G.W., CAMPO, F.M., GREENE, M.C. 2001. Phytoremediation of small-scale oil spills in fresh marsh environment: a mesocosm simulation. Mar. Environ. Res., 52 (3): 195-211. https://doi. org/10.1016/S0141-1136(00)00268-3.

DUKE, N.C., MEYNECKE, J.O., DITTMANN, S., ELLISON, A.M., ANGER, K., BERGER, U., CANNICCI, S., DIELE, K., EWEL, K.C., FIELD, C.D., KOEDAM, N., LEE, S.Y., MARCHAND, C., NORDHAUS, I., DAHDOUH-GUEBAS, F. 2007. A World Without Mangroves? Science, 317 (5834): 41-42. DOI: 10.1126/ science.317.5834.41b.

EVANGELISTA, A.J.A., NASCIMENTO, I.A., PEREIRA, S.A., LOPES, M.B., MARTINS, L.K.P., FILLMANN, G., 2005. Assessing the potential toxicity of marine sediments found in petroleum industry areas: A new approach based on responses of postlarval shrimp. Ciencias Mar. 31 (1A): 43-55. https://doi. org/10.7773/cm.v31i11.79.

GAGLIANONE, P.C., TRINDADE, L.A.F. 1988. Caracterização 
Geoquímica dos óleos da Bacia do Recôncavo. Geochim. Brasiliensis, 2 (1): 15-39. https://doi.org/10.21715/gb.v1i2.13.

GARCIA, K.S., 2005. Biodisponibilidade e toxicidade de contaminantes em sedimentos na porção nordeste da Baía de Todos os Santos. Tese Doutorado, Universidade Federal Fluminense, Niterói.

GUNDLACH, E.R., HAYES, M.O. 1978. Vulnerability of coastal environments to oil spill impacts. Mar. Technol. Soc. J., 12 (4): $18-27$.

HAIMI, J. 2000. Decomposer animals and bioremediation of soils. Environ. Pollut., 107 (2): 233-238. https://doi.org/10.1016/ S0269-7491(99)00142-6.

HAMILTON, M.A., RUSSO, R.C., THURSTON, R. V. 1977. Trimmed Spearman-Karber method for estimating median lethal concentration in toxicity bioassays . Environ. Sci. Technol., 11 (7): 714-719. DOI: 10.1021/es60130a004.

HICKS, G.R.F., COULL, B., 1983. The ecology of marine meiobenthic harpacticoid copepods. Mar. Biol. Ann. Rev. 21: 67-175.

HUANG, L., MA, T., LI, D., LIANG, F.L., LIU, R.L., LI, G.Q. 2008. Optimization of nutrient component for diesel oil degradation by Rhodococcus erythropolis. Mar. Pollut. Bull., 56 (10): 17141718. https://doi.org/10.1016/j.marpolbul.2008.07.007.

KEGLEY, S.E., HILL, B.R., ORME, S., CHOI, A.H., 2011. PAN Pesticide Database.

LIBRALATO, G., MINETTO, D., LOFRANO, G., GUIDA, M., CAROTENUTO, M., ALIBERTI, F., CONTE, B., NOTARNICOLA, M. 2018. Toxicity assesment within the application of in situ contaminated sediment remediation technologies: a review. Sci. Total Environ., 621: 85-94. https:// doi.org/10.1016/j.scitotenv.2017.11.229.

LINDEN, E., BENGTSSON, B.E., SVANBERG, O., SUNDSTROM, G., NATIONAL SWEDISH ENVIRONMENT PROTECTION, B. 1979. The acute toxicity of 78 chemicals and pesticide formulations against two brackish water organisms, the bleak (Alburnus alburnus) and the harpacticoid Nitocra spinipes. Chemosphere, 8 (11-12): 843-851. https://doi.org/10.1016/00456535(79)90015-8.

LOFRANO, G., LIBRALATO, G., MINETTO, D., DE GISI, S., TODARO, F., CONTE, B., CALABRÒ, D., QUATRARO, L., NOTARNICOLA, M. 2017. In situ remediation of contaminated marine sediment: an overview. Environ. Sci. Pollut. Res., 24 (6): 5189-5206. http://dx.doi 10.1007/s11356-016-8281-x.

LORENZEN, C.J. 1967. Determination of chlorophyll and pheopigments: spectrophotometric equations. Limnol. Oceanogr., 12 (2): 343-346. https://doi.org/10.4319/lo.1967.12.2.0343.

LOTUFO, G.R. 1997. Toxicity of sediment-associated PAHs to a estuarine copepod: Effects on survival, feeding, reproduction and behavior. Mar. Environ. Res., 44 (4): 149-166. https://doi. org/10.1016/S0141-1136(96)00108-0.

LOTUFO, G.R., FLEEGER, J.W. 1996. Toxicity of sedimentassociated pyrene and phenanthrene to Limnodrilus hoffmeisteri (Oligochaeta: Tubificidae). Environ. Toxicol. Chem., 15: 15081516. https://doi.org/10.1002/etc.5620150912.

LOTUFO, G.R., FLEEGER, J.W. 1997. Effects of sedimentassociated phenanthrene on survival, development and reproduction of two species of meiobenthic copepods. Mar. Ecol. Prog. Ser., 151: 91-102. https://doi.org/10.3354/meps 151091

MACIEL, D.C., COSTA, B.V.M., SOUZA-SANTOS, L.P., SOUZA, J.R.B., ZANARDI-LAMARDO, E., 2015. Avaliação da toxicidade dos sedimentos do sistema estuarino do rio Capibaribe (Pernambuco, Brasil) utilizando o copépodo bentônico Tisbe biminiensis Volkmann Rocco (1973). Trop. Oceanogr., 43 (1): 26-37. https://doi.org/10.5914/tropocean.v43i1.5882.
MILLER, C.A., GLIBERT, P.M. 1998. Nitrogen excretion by the calanoid copepod Acartia tonsa: results of mesocosm experiments. J. Plankton Res., 20 (9): 1767-1780. https://doi. org/10.1093/plankt/20.9.1767.

MILLS, M.A., BONNER, J.S., MCDONALD, T.J., PAGE, C.A., AUTENRIETH, R.L. 2003. Intrinsic bioremediation of a petroleum-impacted wetland. Mar. Pollut. Bull., 46 (7): 887899. https://doi.org/10.1016/S0025-326X(02)00367-3.

MILLS, M.A., BONNER, J.S., PAGE, C.A., AUTENRIETH, R.L. 2004. Evaluation of bioremediation strategies of a controlled oil release in a wetland. Mar. Pollut. Bull., 49 (5-6): 425-435. https://doi.org/10.1016/j.marpolbul.2004.02.027.

MUELLER, D.C., BONNER, J.S., MCDONALD, S.J., AUTENRIETH, R.L., DONNELLY, K.C., LEE, K., DOE, K., ANDERSON, J. 2003. The use of toxicity bioassays to monitor the recovery of oiled wetland sediments. Environ. Toxicol. Chem., 22 (9): 1945-1955. https://doi.org/10.1897/02-325.

NASCIMENTO, A., SMITH, D.H., PEREIRA, S.A., DE ARAÚJO, M.M.S., SILVA, M.A., MARIANI, A.M. 2000. Integration of varying responses of different organisms to water and sediment quality at sites impacted and not impacted by the petroleum industry. Aquat. Ecosyst. Heal. Manag., 3 (4): 449-458. https:// doi.org/10.1016/S1463-4988(00)00045-2.

NIKOLOPOULOU, M., KALOGERAKIS, N. 2008. Enhanced bioremediation of crude oil utilizing lipophilic fertilizers combined with biosurfactants and molasses. Mar. Pollut. Bull., 56 (11): 1855-1861. https://doi.org/10.1016/j.marpolbul.2008.07.021.

OLIVEIRA, D.D., SOUZA-SANTOS, L.P., SILVA, H.K.P., MACEDO, S.J. 2014. Toxicity of sediments from a mangrove forest patch in an urban area in Pernambuco (Brazil). Ecotoxicol. Environ. Saf., 104 (1): 373-378. https://doi.org/10.1016/j. ecoenv.2014.02.004.

ORGE, M.D.R., PORSCHÉ, I.J., COSTA, M.C., LIMA, J.S., SOARES, S.E.D., JUSTINO, R. 2000. Assessment of oil refinery waste on Rhizophora mangle L. seedling growth in mangrove of Todos os Santos Bay, Bahia, Brazil. Aquat. Ecosyst. Heal. Manag., 3: 471-477. https://doi.org/10.1016/ S1463-4988(00)00042-7.

PASCAL, P.Y., DUPUY, C., RICHARD, P., MALLET, C., DU CHATELET, E.A., NIQUIL, N. 2009. Seasonal variation in consumption of benthic bacteria by meio- and macrofauna in an intertidal mudflat. Limnol. Oceanogr., 54 (4): 1048-1059. https://doi.org/10.4319/1o.2009.54.4.1048.

PESO-AGUIAR, M.C., SMITH, D.H., ASSIS, R.C.F., SANTAISABEL, L.M., PEIXINHO, S., GOUVEIA, E.P., ALMEIDA, T.C.A., ANDRADE, W.S., CARQUEIJA, C.R.G., KELMO, F., CARROZZO, G., RODRIGUES, C. V, CARVALHO, G.C., JESUS, A.C.S. 2000. Effects of petroleum and its derivates in benthic communities at Baía de Todos os Santos/Todos os Santos Bay, Brazil. Aquat. Ecosyst. Heal. Manag., 3: 459-470. https://doi.org/10.1016/S1463-4988(00)00051-8.

PINTO, C.S.C., SOUZA-SANTOS, L.P., SANTOS, P.J.P. 2001. Development and population dynamics of Tisbe biminiensis (Copepoda: Harpacticoida) reared on different diets. Aquaculture 198: 253-267. https://doi.org/10.1016/S00448486(00)00582-2.

PRINCE, R.C. 1993. Petroleum spill bioremediation in marine environments. Crit. Rev. Microbiol., 19: 217-242. https://doi. org/10.3109/10408419309113530.

RAMSAY, M.A., SWANNELL, R.P.J., SHIPTON, W.A., DUKE, N.C., HILL, R.T. 2000. Effect of bioremediation on the microbial community in oiled mangrove sediments. Mar. Pollut. Bull., 41 (7-12): 413-419. https://doi.org/10.1016/ S0025-326X(00)00137-5. 
RIBEIRO, A.C.B., SOUZA-SANTOS, L.P. 2011. Mass culture and offspring production of marine harpacticoid copepod Tisbe biminiensis. Aquaculture, 321 (3-4): 280-288. https://doi. org/10.1016/j.aquaculture.2011.09.016.

SABEAN, J.A.R., SCOTT, D.B., LEE, K., VENOSA, A.D. 2009. Monitoring oil spill bioremediation using marsh foraminifera as indicators. Mar. Pollut. Bull., 59 (8-12): 352-361. https:// doi.org/10.1016/j.marpolbul.2009.08.013.

SANTOS, P.J.P., BOTTER-CARVALHO, M.L., DO NASCIMENTO, A.B., MARINHO, R.G.C., CARVALHO, P.V.V.C., VALENCA, A.P.M.C. 2009. Response of estuarine meiofauna assemblage to effects of fertilizer enrichment used in the sugar cane monoculture. Pernambuco, Brazil. Brazilian J. Oceanogr., 57 (1): 43-55. http://dx.doi.org/10.1590/S167987592009000100005.

SCHRATZBERGER, M., DANIEL, F., WALL, C.M., KILBRIDE, R., MACNAUGHTON, S.J., BOYD, S.E., REES, H.L., LEE, K., SWANNELL, R.P.J. 2003. Response of estuarine meioand macrofauna to in situ bioremediation of oil-contaminated sediment. Mar. Pollut. Bull., 46 (4): 430-443. https://doi. org/10.1016/S0025-326X(02)00465-4.

SILVA, F.C. 1999. Manual de análises químicas de solo, plantas e fertilizantes. Embrapa Comunicação para Transferência de Tecnologia, Brasília.

SMITH, V.H., GRAHAM, D.W., CLELAND, D.D. 1998. Application of resource-ratio theory to hydrocarbon biodegradation. Environ. Sci. Technol., 32 (21): 3386-3395. DOI: 10.1021/ es9805019.

VENTURINI, N., MUNIZ, P., BICEGO, M.C., MARTINS, C.C., TOMMASI, L.R. 2008. Petroleum contamination impact on macrobenthic communities under the influence of an oil refinery: Integrating chemical and biological multivariate data. Estuar. Coast. Shelf Sci., 78 (3): 457-467. https://doi. org/10.1016/j.ecss.2008.01.008.
VENTURINI, N., TOMMASI, L.R. 2004. Polycyclic aromatic hydrocarbons and changes in the trophic structure of polychaete assemblages in sediments of Todos os Santos Bay, Northeastern, Brazil. Mar. Pollut. Bull., 48 (1-2): 97-107. https://doi.org/10.1016/S0025-326X(03)00331-X.

WALKEY-BLACK, A. 1947. A critical examination of a rapid method for determining organic carbon in soils: effect of variations in digestion conditions and of inorganic soil constituents. Soil Sci., 63: 251-263. DOI:10.1097/00010694194704000-00001.

WIRTH, E.F., FULTON, M.H., CHANDLER, G.T., KEY, P.B., SCOTT, G.I., 1998. Toxicity of sediment associated PAHs to the estuarine crustaceans, Palaemonetes pugio and Amphiascus tenuiremis. Bull. Environ. Contam. Toxicol., 61: 637-644. https://doi.org/10.1007/s001289900808.

XU, R., LAU, A.N.L., LIM, Y.G., OBBARD, J.P. 2005 a. Bioremediation of oil-contaminated sediments on an intertidal shoreline using a slow-release fertilizer and chitosan. Mar. Pollut. Bull., 51 (8-12): 1062-1070. https://doi.org/10.1016/j. marpolbul.2005.02.049.

XU, R., YONG, L.C., LIM, Y.G., OBBARD, J.P. 2005b. Use of slowrelease fertilizer and biopolymers for stimulating hydrocarbon biodegradation in oil-contaminated beach sediments. Mar. Pollut. Bull., 51 (8-12): 1101-1110. https://doi.org/10.1016/j. marpolbul.2005.02.037.

YU, K.S.H., WONG, A.H.Y., YAU, K.W.Y., WONG, Y.S., TAM, N.F.Y. 2005. Natural attenuation, biostimulation and bioaugmentation on biodegradation of polycyclic aromatic hydrocarbons (PAHs) in mangrove sediments. Mar. Pollut. Bull., 51: 1071-1077. https://doi.org/10.1016/j. marpolbul.2005.06.006. 